\title{
Effect of infield handling conditions and time to pre-cooling on the shelf-life and quality of tomatoes
}

\author{
Efeito das condições de manuseio no campo e do tempo antes do pré-resfriamento na \\ vida de prateleira e qualidade de tomates
}

\author{
Kipchumba Cherono ${ }^{1 *}$, Milindi Sibomana', Tilahun Seyoum Workneh ${ }^{1}$ \\ ${ }^{1}$ University of KwaZulu-Natal, School of Engineering, Bioresources Engineering Research Group, Scottsville, Pietermaritzburg - South Africa
}

\section{*Corresponding Author}

Kipchumba Cherono, University of KwaZulu-Natal, School of Engineering, Bioresources Engineering Research Group, Private bag X01, 3209 Scottsville, Pietermaritzburg - South Africa, e-mail: kip.cherono@gmail.com

Cite as: Effect of infield handling conditions and time to pre-cooling on the shelf-life and quality of tomatoes. Braz. J. Food Technol., v. 21, e2017016, 2018.

Received: Feb. 22, 2017; Accepted: Dec. 12, 2017

\section{Abstract}

This study investigates the effects of post-harvest handling practices prior to storage on the quality of tomatoes in South African supply chains. Pink mature tomatoes were harvested in the morning and afternoon, transported from two farms located $40 \mathrm{~km}$ apart to two central pack houses located near each of the farms in Limpopo, South Africa. The samples were transported using bins (468 $\mathrm{kg}$ capacity) and lugs (20 kg capacity). After harvesting, the samples were either immediately transported to the pack house and precooled within two hours, or left in the field and transported to the pack house to be pre-cooled after six hours, to simulate delays during transportation. On arrival at the pack houses, the fruit was sampled from the bottom $0.15 \mathrm{~m}$ of each lug or bin, precooled using forced air and washed. After precooling, the samples were stored either under ambient conditions or refrigerated storage $\left(15 \pm 2{ }^{\circ} \mathrm{C}\right)$. The tomato colour, firmness, weight loss, marketability and $\mathrm{pH}$ were monitored over a 24-day storage period. The rate of change of the fruit hue angle was significantly $(p \leq 0.05)$ higher for samples handled using bins as compared to those handled using lugs. Handling conditions had no significant $(p>0.05)$ effect on the rate of loss of fruit flesh firmness. The bottom layer of fruit stored in bins showed $30 \%$ mechanical damage as compared to $2 \%$ in lugs. Harvesting in the morning and pre-cooling within two hours improved fruit marketability and weight-loss by up to $200 \mathrm{~kg} / \mathrm{ton}$ and $75 \mathrm{~kg} / \mathrm{ton}$, respectively, as compared to harvesting in the afternoon and pre-cooling after six hours. As the best practices for industry, the study recommends minimizing the time to pre-cooling, harvesting in the morning and using lugs to handle the fresh tomatoes.

Keywords: Effect of transportation; Bin; Lug; Postharvest quality losses; Postharvest practices.

\section{Resumo}

Este estudo investiga os efeitos das práticas de manuseio pós-colheita, antes do armazenamento, na qualidade de tomates na cadeia de suprimento na África do Sul. Tomates maduros cor-de-rosa foram colhidos de manhã e, de tarde, transportados de duas fazendas distantes $40 \mathrm{~km}$ uma da outra, até dois armazéns centrais, localizados perto das fazendas, em Limpopo, África do Sul. As amostras foram transportadas em engradados plásticos (capacidade de $468 \mathrm{~kg}$ ) ou caixas plásticas (capacidade de $20 \mathrm{~kg}$ ). Depois da colheita, criaram-se duas situações: i) amostras foram imediatamente transportadas até o armazém e pré-resfriadas dentro de duas horas, e ii) amostras foram deixadas no campo e transportadas até o armazém para serem pré-resfriadas após seis horas, para simular atrasos no transporte. Ao chegar ao armazém, uma amostra da fruta foi retirada de uma altura de $0,15 \mathrm{~m}$ do fundo do engradado e da caixa, pré-resfriada com ar forçado e lavada. Após o pré-resfriamento, as amostras foram estocadas em condições ambientais ou sob refrigeração $\left(15 \pm 2{ }^{\circ} \mathrm{C}\right)$. Os parâmetros cor, firmeza, perda de peso, potencial para vender e pH dos tomates foram monitorados durante um período de 24 dias. A taxa de mudança do ângulo de cor da fruta foi significativamente $(p \leq 0,05)$ mais alta para as amostras manuseadas usando engradados do que para aquelas manuseadas em caixas menores. Quanto às condições de manuseio, não houve efeito significativo $(p>0,05)$ na taxa de perda da firmeza da fruta. A camada de fruta estocada no fundo dos engradados 
demonstrou 30\% a mais de danos mecânicos, quando comparada com apenas 2\% desses danos nas caixas menores. Colheita de manhã e pré-resfriamento em menos de 2 horas melhoraram as condições das frutas para venda e diminuíram as perdas de peso de até $200 \mathrm{~kg} /$ tonelada para $75 \mathrm{~kg} /$ tonelada, quando comparadas com a colheita à tarde e pré-resfriamento após 6 horas. Como boas práticas para indústria, este estudo recomenda minimizar o tempo antes do pré-resfriamento, colher de manhã e estocar os tomates frescos em caixas menores.

Palavras-chave: Efeito de transporte; Engradado; Caixa; Perdas de qualidade após a colheita; Práticas pós-colheita.

\section{Introduction}

Fresh tomato fruit is an important consumer product and a valuable industrial commodity (BECKLES, 2012). It is consumed in virtually all cultures and countries in the world and enjoys global appeal in meal preparation (BECKLES, 2012; ARAH et al., 2015). In South Africa, tomato production contributes $24 \%$ of the total gross fresh fruit and vegetable (FFV) production (SADAFF, 2015). The Limpopo province is the major growing area, accounting for over $75 \%$ of the total planted area, with the commercial large-scale growers producing nearly $95 \%$ of the total tomato output (SADAFF, 2015).

Due to its climacteric nature, tomato fruit is highly perishable and its quality starts to deteriorate immediately after harvest. The rate of quality degradation is influenced by both pre- and post-harvest factors (ARAH et al., 2015). Some of the pre-harvest factors include plant stress, crop production practices and genetic factors. Post-harvest factors include handling and storage conditions during and after harvest, and are important agents that can be used to manage post-harvest quality deterioration in FFV supply chains.

In the last 30 years, extensive research in improving the pre-harvest factors affecting tomato production has resulted in an increase in global yield by $37 \%$ (FAO, 2015). There is, however, a need for investment in post-harvest quality management, as it has been shown that in some regions of Africa, postharvest tomato losses are as high as $40 \%$ (MACHEKA et al., 2017). There is a scarcity of information quantifying the level of post-harvest losses in the South African tomato supply chains, although recent estimates by Sibomana et al. (2016) present it to be $10.2 \%$ of the total production. Transportation and post-harvest infield handling practices have been cited as some of the drivers of post-harvest loss downstream in commercial supply chains (ETEBU et al., 2013).

The quality deterioration of FFV is time and temperature dependent (JEDERMANN et al., 2017) and deteriorative processes continually occur during harvest and postharvest. It is therefore important to minimize the time before the precooling of harvested produce, coupled with other appropriate measures to minimize the damaging effect of the accumulation of field heat, in order to maximize the shelf-life of such products (RAB et al., 2013). It has been generally established that every hour in the delay of precooling after harvesting causes a loss of one day in the shelf-life of harvested tomato (ARAH et al., 2015). Similarly, the accumulation of field heat in harvested fruit can be minimized by scheduling harvesting periods to cooler times of the day (ARAH et al., 2015).

There are numerous studies that have investigated the effect of pre-cooling on the shelf-life and quality of tomato (RAB et al., 2013). However, none of these studies has accounted for practicalities in the commercial supply chains, particularly the logistical backlogs that hinder efficient and quick transportation of harvested produce from the field to the cooling units. This study aims to establish the effect of time before pre-cooling, harvesting time, handling and storage conditions on the quality and shelf-life of commercially produced fresh tomatoes in South Africa.

\section{Material and methods}

\subsection{Tomato fruit samples}

Tomatoes (Solanum lycopersicum cv. Nemo-Netta) at the pink maturity stage were harvested from two farms in the Limpopo province, South Africa, situated in Rietpol (2347'2.335" S 29²9'59.189" E) and Dikgale (2339'22.903" S $29^{\circ} 45^{\prime} 16.117^{\prime \prime} \mathrm{E}$ ) during the late summer season (harvested on $25^{\text {th }}$ March 2016). The tomatoes from the Rietpol and Dikgale farms were then transported to their respective pack-houses situated at 23⒋'0.103" S 29³5'5.362" E (PH1) and 2339'53.294" S 2945'1.151" E (PH2), respectively. These farms and pack-houses typified operations of some of the largest commercial tomato growers in South Africa. During transportation, the sample tomatoes were packed in either a large plastic crate referred to as a bin $(2 \mathrm{~m} \times 1 \mathrm{~m} \times 0.4 \mathrm{~m})$, or smaller plastic crate, referred to as a lug $(0.5 \mathrm{~m} \times 0.4 \mathrm{~m} \times 0.3 \mathrm{~m})$. On each farm, two bins and lugs were harvested in the morning (07:00) and another set harvested in the afternoon (13:00). One bin and one lug were immediately transported to the pack-house after harvesting, and pre-cooled within two hours after harvesting, while the other set was left outside and pre-cooled 6 hours later to simulate logistical delays. The pack houses in Rietpol and Dikgale were $20 \mathrm{~km}$ and $5 \mathrm{~km}$ respectively, from the field where the fruit was harvested. A pictorial presentation of the bin and the lug is shown in Figure 1. 

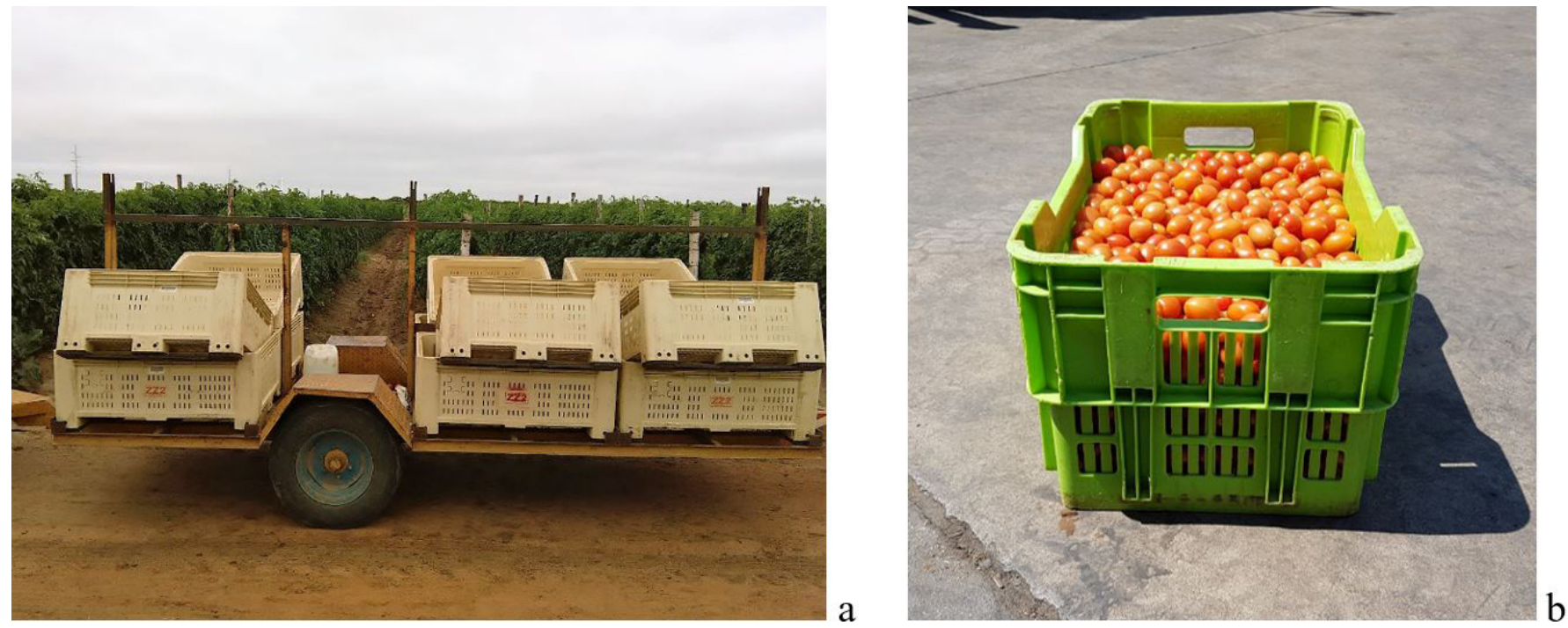

Figure 1. Photographic presentations of the large plastic bins (a) and smaller lugs (b) used to transport tomato fruits to the pack houses under commercial conditions.

\subsection{Sample preparation}

On receiving the samples at the pack-house, the samples were pre-cooled in a forced-air mechanical cooler (Carrier, USA) until they reached $13^{\circ} \mathrm{C}$, which typically took $1 \pm 0.25$ hours. 120 fruits were then sampled from the bottom $0.15 \mathrm{~m}$ of each bin or lug, and dipped in $0.1 \% \mathrm{v} / \mathrm{v}$ Sporekill ${ }^{\otimes}$ (ICA International chemicals Pty, Stellenbosch, South Africa), a fresh fruit disinfectant containing $120 \mathrm{~g} / \mathrm{L}$ didecyldimethyl ammonium chloride for 3 minutes. The excess Sporekill ${ }^{\circledR}$ solution was blotted off from the fruit surfaces using a paper towel, and the fruits placed in a carton $(0.4 \mathrm{~m} \times 0.3 \mathrm{~m} \times 0.25 \mathrm{~m})$ with 30 fruits in each carton. The cartons were stored under ambient conditions or in cold storage units set to operate at $13-17^{\circ} \mathrm{C}$.

\subsection{Experimental design}

The experiment was set up using a Randomized Complete Block Design, with the two handling conditions (bins and lugs), two harvesting times (morning and afternoon), two storage temperatures (ambient and cold storage) and two times before pre-cooling ( 2 hours and 6 hours) as the factors. The two pack-houses were used as the blocks. The experiment was replicated twice, and the four boxes of fruit from each lug and bin randomly assigned to the two storage environments.

\subsection{Data collection}

Tomato fruit colour, firmness, product temperature, marketability, weight loss and $\mathrm{pH}$ were measured over a 24-day storage period, with sampling on day 0 , and after $4,8,16$ and 24 days of storage. On-site assessment of these quality parameters was carried out as follows:

\subsubsection{Fruit temperature}

The surface temperature of six fruits from each replicate was measured using an infrared thermometer (ST677, AssTech Instrumentation, Randburg, South Africa).

\subsubsection{Colour}

The colour of the six fruits from each replicate was measured using a Konica Minolta Chroma meter (Model CR-400, Narachi Pty, South Africa). Readings were taken at an observer angle of $2^{\circ}$ after standardizing the instrument with a white tile $(Y=93.8, X=0.3030, y=0.3191)$. The $L^{*} a^{*} b^{*}$ and $h$ values were reported for each reading (CARON et al., 2013).

\subsubsection{Firmness}

Firmness was measured according to the procedure described by Polenta et al. (2015). Briefly, the fresh fruit firmness (FFf) of six tomato fruits from each replicate was assessed using a durometer (Analog HP mechanical fruit firmness tester, Lauderdale, Florida, USA). Each fruit was tested at three adjacent sites of its equatorial axis and the readings averaged.

\subsection{4 pH}

The fruit $\mathrm{pH}$ value was measured using the procedure described by Tigist et al. (2013) as follows: Three fruits from each replicate were each macerated in a fruit blender (Phillips model HR2103, Makro Pty, Pietermaritzburg South Africa) for one minute, and the juice passed through a muslin cloth into a beaker. The $\mathrm{pH}$ of the juice was then measured using a portable $\mathrm{pH}$ meter (HI98118, Hanna instruments Pty, Johannesburg, South Africa). The data were recorded in triplicate. 


\subsubsection{Weight loss}

The weight loss of each tomato fruit sample was measured by labelling and weighing two batches of three fruits from each replicate on each sampling day. This procedure followed the method described by Caron et al. (2013).

\subsubsection{Subjective quality analysis}

The subjective quality assessment of the stored products was carried out as follows: A visual assessment of the decay, shrinkage and emergence of post-harvest disorders was made for the fruits in each box. Marketability was estimated according to Workneh et al. (2012), where, on each sampling day, fruit that would ordinarily be sellable was quantified as a percentage of the initial quantity of stored fruit. Damaged, decayed or overripe fruits were considered unmarketable, and were removed from the stored samples.

\subsection{Data analysis}

All the data collected was analysed using SPSS version 24 (IBM, USA). The general analysis of variance was used to assess the effects of handling conditions, harvesting time, time before pre-cooling and storage conditions on the shelf-life, quality and marketability of the stored tomatoes under infield storage conditions. The rate of change in colour and firmness was calculated for each storage interval. Colour and firmness models were developed by fitting the Weibull kinetic equation to the experimental data. Equation 1 is the Weibull kinetic equation, given as,

$$
\frac{C}{C_{0}}=e^{-k t^{n}}
$$

where: $\mathrm{C}$ is the quality measured after a storage period $\mathrm{t}$ (days), $\mathrm{k}$ the rate constant at a constant temperature $\left(\right.$ day $\left.^{-1}\right), \mathrm{n}$ is the order of reaction and $\mathrm{C}_{0}$ designates the quality parameter at time $\mathrm{t}=0$. The Weibull model reduces to a first order kinetic model when $n=1$.

The models developed were used to predict the colour and firmness of the fruit based on the storage period. Matlab's curve fitting tool box (R2010a, Mathworks, USA) was used to estimate the model parameters and the goodness of fit reported in terms of the model's correlation coefficient $\left(\mathrm{R}^{2}\right)$. This method was suggested by Pinheiro et al. (2015).

\section{Results and discussion}

\subsection{Storage temperature conditions}

The variation in ambient and fruit surface temperature of the fruit stored in $\mathrm{PH} 1$ and $\mathrm{PH} 2$ are shown in Figure 2a and Figure 2b, respectively. The ambient and surface temperature of the fruit samples stored in $\mathrm{PH} 2$ were
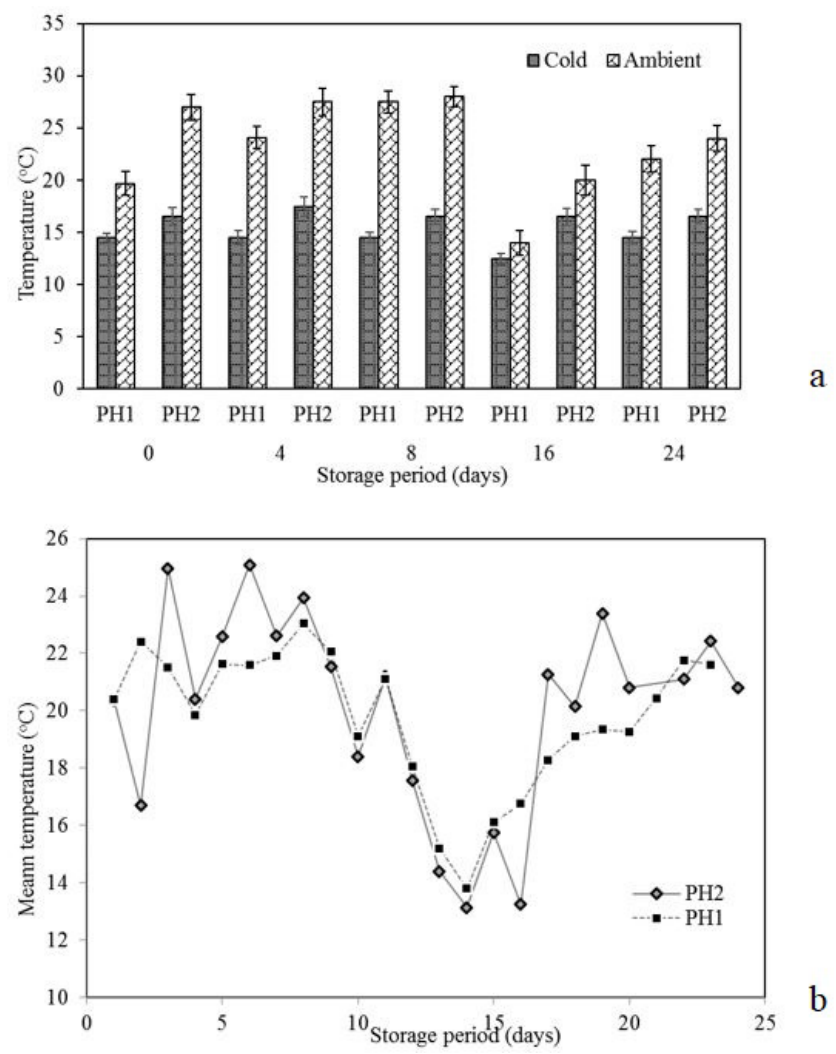

Figure 2. Surface temperature of tomato fruit stored under ambient and cold storage conditions (a) and the ambient temperature conditions in Rietpol (PH1) and Digale (PH2) pack-houses (b).

higher than those of fruits stored in $\mathrm{PH} 1$. Higher ambient temperature conditions resulted in higher fruit surface temperature in the fruit stored in $\mathrm{PH} 2$ as compared to that of fruit stored in $\mathrm{PH} 1$. The storage temperature conditions play an important role in determining the rate of degradation of fresh fruits, and are therefore the key driver of fruit quality changes during storage.

\subsection{Fruit quality changes}

\subsubsection{Colour}

The hue angle $(h)$ measures the colour of food products on a $360^{\circ}$ colour space (PINHEIRO et al., 2015). Angles of $90^{\circ}$ are assigned to a yellow hue, $180^{\circ}$ green hue, $270^{\circ}$ blue hue and $0^{\circ}$ red hue (PINHEIRO et al., 2015). The $h$ value of the fruit gradually reduced during the storage period for all treatment conditions, typifying the progression of ripening as the colour changed from green to red. There was a significant $(p \leq 0.05)$ reduction in the $h$ value between successive sampling days during the storage period. The handling conditions and harvesting time had a significant ( $p \leq 0.05)$ effect on the $h$ values of the samples stored in $\mathrm{PH} 1$. The time before pre-cooling had no significant $(p>0.05)$ effect on the $h$ of tomato fruit handled and stored in $\mathrm{PH} 1$. 
Effect of infield handling conditions and time to pre-cooling on the shelf-life and quality of tomatoes

Cherono, K. et al.

Similarly, the $h$ value reduced gradually during the storage period for samples stored in $\mathrm{PH} 2$, with significant changes ( $p \leq 0.05$ ) between sampling days 0, 4, 8 and 16 . The difference in $h$ between sampling days 16 and 24 was, however, not significant $(p>0.05)$. This may be attributed to a higher rate of deterioration of these samples due to the relatively higher temperature conditions in $\mathrm{PH} 2$ as compared to $\mathrm{PH} 1$ (Figure 2b). The handling conditions of the fruit samples stored in $\mathrm{PH} 2$ were the only significant $(p \leq 0.05)$ factor affecting the reduction in $h$. As expected, the reduction in $h$ of tomatoes stored under ambient conditions was greater than those stored in cold storage, due primarily to the natural relationship between temperature and the rate of biochemical reactions. The samples handled using bins also showed a higher rate of colour change compared to those handled using lugs in both pack houses (Figure 3). In PH1, the best treatment for fruit stored under cold storage was to precool within 2 hours
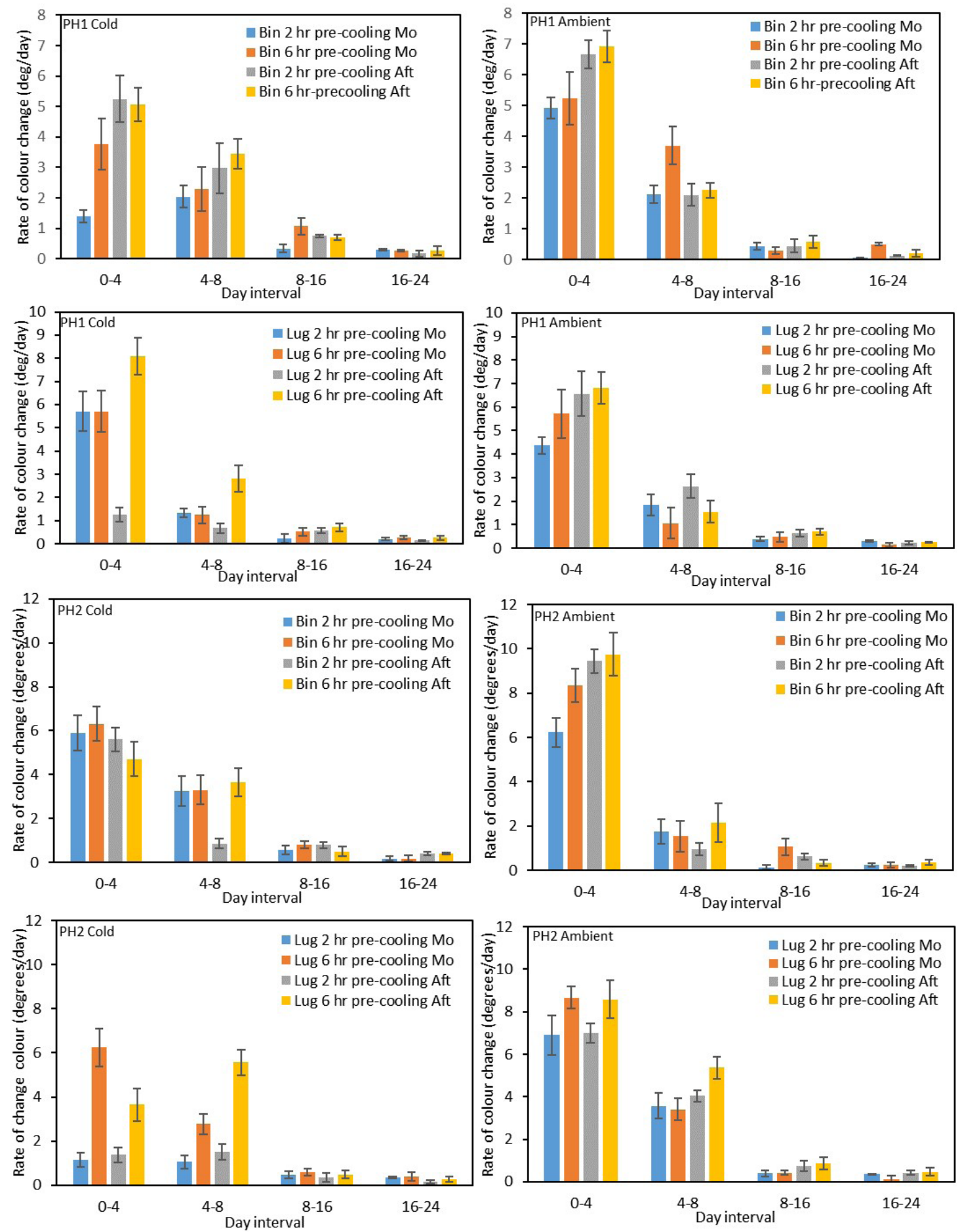

Figure 3. Effect of various treatments on the rate of colour change. 
of harvest (2 hour-precooled) and harvest in the morning for bins, and precool within 2 hours of harvest and harvest in the afternoon for lugs, whilst for the ambient stored samples the best treatment for both bins and lugs was to precool within 2 hours of harvest and harvest in the morning. In PH2, the samples stored in cold storage and handled using bins, 2 hour-precooled and harvested in the afternoon appeared to retain their colour best, whereas for those handled using lugs, harvesting in the morning and precooling within 2 hours clearly showed the lowest rate of change in colour. In ambient stored samples handled in both lugs and bins, morning harvesting and 2 hourprecooling were the best conditions in terms of colour retention. The rate of colour change as indicated by $h$ peaked between days 0 and 4 of storage, and subsequently decreased (Figure 3), an observation corroborated by Hurr et al. (2005). The colour change in tomato fruits in other maturity stages behaved differently (HURR et al., 2005). For instance, the study by Tadesse et al. (2015) showed that the rate of colour degradation of mature green tomato peaked between days 4 and 8 . This observation underscores the importance of using handling practices that reduce the rate of deteriorative processes that occur immediately after harvest, such as minimising the time before precooling and the subsequent maintenance of the cold chain of pink harvested tomato. The colour change expressed as the rate of reduction in $h$, also appeared to follow an exponential decay function (Figure 3). It has been well established that the degradation of colour components in fresh fruits follows first order reaction kinetics that render it possible to obtain the temperature dependent kinetic constants (MOURA et al., 2011). These constants increase concomitantly with the storage temperature, following the Arrhenius law (PINHEIRO et al., 2015), which may explain the higher rate of colour change in ambient stored tomatoes as compared to cold stored tomatoes.

The reduction in the time before precooling and scheduling the harvest for cooler times of the day, had a beneficial effect on the colour of the harvested tomatoes, and these are important contributors in maintaining tomato quality. In the context of this study, although the time before precooling showed a smaller positive effect on tomato fruit colour, Acedo Junior et al. (2009) recommended hydro-cooling as an effective alternative to room and forced air cooling. However, strategies to manage fruit decay should be applied, since hydro-cooling may promote fruit decay. Combining hydro-cooling with the use of disinfectant solutions during wet dumping may be suggested to the industry as the first step in efficiently removing field heat.

In South Africa, tomato consumers prefer pink to light-red tomatoes due to their perceived freshness, and because they consider red tomatoes to have a shorter shelf-life, resulting in an association with a lower market value (VERMEULEN; BIENABE, 2010). Colour maintenance by improving handling and harvesting conditions is one of the routes to improving the quality and market value of commercially produced tomatoes in South Africa.

The kinetic model functions developed for tomato fruit colour fitted the Weibull model well, with $\mathrm{R}^{2}$ values well over 0.97 (Table 1). The predicted shelf life, based on the colour ( $h=45$ ) of the fruit from the different treatments, was 28 days for fruit stored in $\mathrm{PH} 1$ under cold storage, 26 days for fruit stored in $\mathrm{PH} 1$ under ambient conditions, 37 days for cold stored fruit in $\mathrm{PH} 2$, and 20 days for ambient stored fruit in $\mathrm{PH} 2$.

\subsubsection{Fruit Flesh firmness (FFf) value}

Fruit flesh firmness gradually decreased during the storage period and was significantly $(p \leq 0.05)$ lower on each successive sampling day for samples stored in both $\mathrm{PH} 1$ and $\mathrm{PH} 2$. Time before pre-cooling and the storage conditions had a significant $(p \leq 0.05)$ effect on product firmness in $\mathrm{PH} 1$, while time before precooling, harvesting time and storage conditions significantly $(p \leq 0.05)$ influenced product firmness in $\mathrm{PH} 2$. The rate of firmness reduction was comparatively higher for ambient stored samples than for those stored in cold storage, a phenomenon expected from a physiological perspective

Table 1. Kinetic parameters and the associated 95\% confidence intervals (Cl) for tomato fruit colour and firmness under ambient and cold storage environments: $\mathrm{PH} 1$ and $\mathrm{PH} 2$ designate fruit harvested and stored in the Rietpol and Dikgale pack houses, respectively.

\begin{tabular}{|c|c|c|c|c|c|}
\hline \multirow{2}{*}{$\begin{array}{c}\text { Quality } \\
\text { parameter }\end{array}$} & \multirow{2}{*}{ Storage environment+ Pack house } & \multicolumn{4}{|c|}{ Model parameters } \\
\hline & & k (95\% Cl for k) & $C_{0}$ & $\mathbf{R}^{2}$ & n (95\% Cl for $n)$ \\
\hline \multirow{4}{*}{ Colour } & Cold $+\mathrm{PH} 1$ & $0.1989(0.08284,0.3149)$ & 86.35 & 0.9847 & $0.3636(0.1397,0.5875)$ \\
\hline & Ambient+PH1 & $0.2428(0.09189,0.3936)$ & 80.42 & 0.9792 & $0.2594(0.01746,0.5013)$ \\
\hline & Cold+PH2 & $0.3105(0.1472,0.4739)$ & 97.00 & 0.9861 & $0.2505(0.04361,0.4573)$ \\
\hline & Ambient+PH2 & $0.2168(0.05527,0.3782)$ & 96.60 & 0.9750 & $0.3860(0.09882,0.6732)$ \\
\hline \multirow{4}{*}{ Firmness } & Cold+PH1 & $0.003139(0.001001,0.005277)$ & 90.08 & 0.7153 & 1 \\
\hline & Ambient+PH1 & $0.01181(0.009711,0.01391)$ & 89.27 & 0.9622 & 1 \\
\hline & Cold+PH2 & $0.005238(0.00356,0.006916)$ & 95.20 & 0.8979 & 1 \\
\hline & Ambient+PH2 & $0.01243(0.008744,0.01611)$ & 93.41 & 0.8930 & 1 \\
\hline
\end{tabular}

$\mathrm{k}$ is the rate constant (day $\left.{ }^{-1}\right), \mathrm{C}_{0}$ the quality parameter at time $t=0, \mathrm{n}$ a model constant and $\mathrm{R}^{2}$ is the coefficient of determination. 
due to the temperature difference between the two storage conditions (Figure 2b). It was somewhat surprising that the handling conditions appeared to have no significant $(p>0.05)$ effect on the rate of reduction in firmness of samples stored in $\mathrm{PH} 1$ and $\mathrm{PH} 2$. Shorter times before pre-cooling and cooler harvesting periods had a positive effect in retarding the rate of firmness loss in cold stored samples in $\mathrm{PH} 2$ (Figure 4). However, samples in ambient storage in $\mathrm{PH} 2$ showed a minimal improvement in the loss of firmness even with shorter times before pre-cooling and cooler harvesting times. A similar observation was also made for cold stored samples in $\mathrm{PH} 1$. In contrast, shorter times before pre-cooling and harvesting at cooler times of the day were important factors in slowing firmness loss for ambient stored samples in $\mathrm{PH} 1$. The rate of firmness reduction peaked between day 4 and 8 (Figure 4), and declined during the subsequent storage periods. This is consistent with observations by Tijskens et al. (1998), who showed that polygalacturonase (PG) activity in stored fruit peaked between days 4 and 7 , depending on the storage temperature. Another study by Hurr et al. (2005) observed an increased rate in the reduction in firmness of pink mature tomatoes during a 2-4 day interval during storage at $20^{\circ} \mathrm{C}$. In the same study, fruit of other maturity stages behaved differently. This suggests that the kinetics of firmness degradation in tomato is dependent on the storage temperature and maturity stage. It appears that the reduction in firmness of fruit stored under lower temperature conditions depicted exponential, first order kinetics (Figure 4). Pinheiro et al. (2013) suggested that the kinetics of tomato firmness followed the Arrhenius fractional conversion kinetic model.

Firmness loss in tomato is an enzymatically controlled process that results in its reduction due to the breakdown of cellulose, pectin and lignin by pectinesterase (PE), polygalacturonase (PG) and $\beta$-galacturose ( $\beta$-gal) in the cell wall (TIGIST et al., 2013). Enzyme controlled processes are temperature dependent. The factors that significantly affected product firmness in the two pack-houses were different. Temperature control may be the underlying factor for this difference, where the time before pre-cooling or cold storage were important in maintaining the cold chain in $\mathrm{PH}$, while all the other factors except the handling condition were important in $\mathrm{PH} 2$. The shorter transport distance may be the underlying factor explaining the non-significance of the handling condition as an important factor in controlling
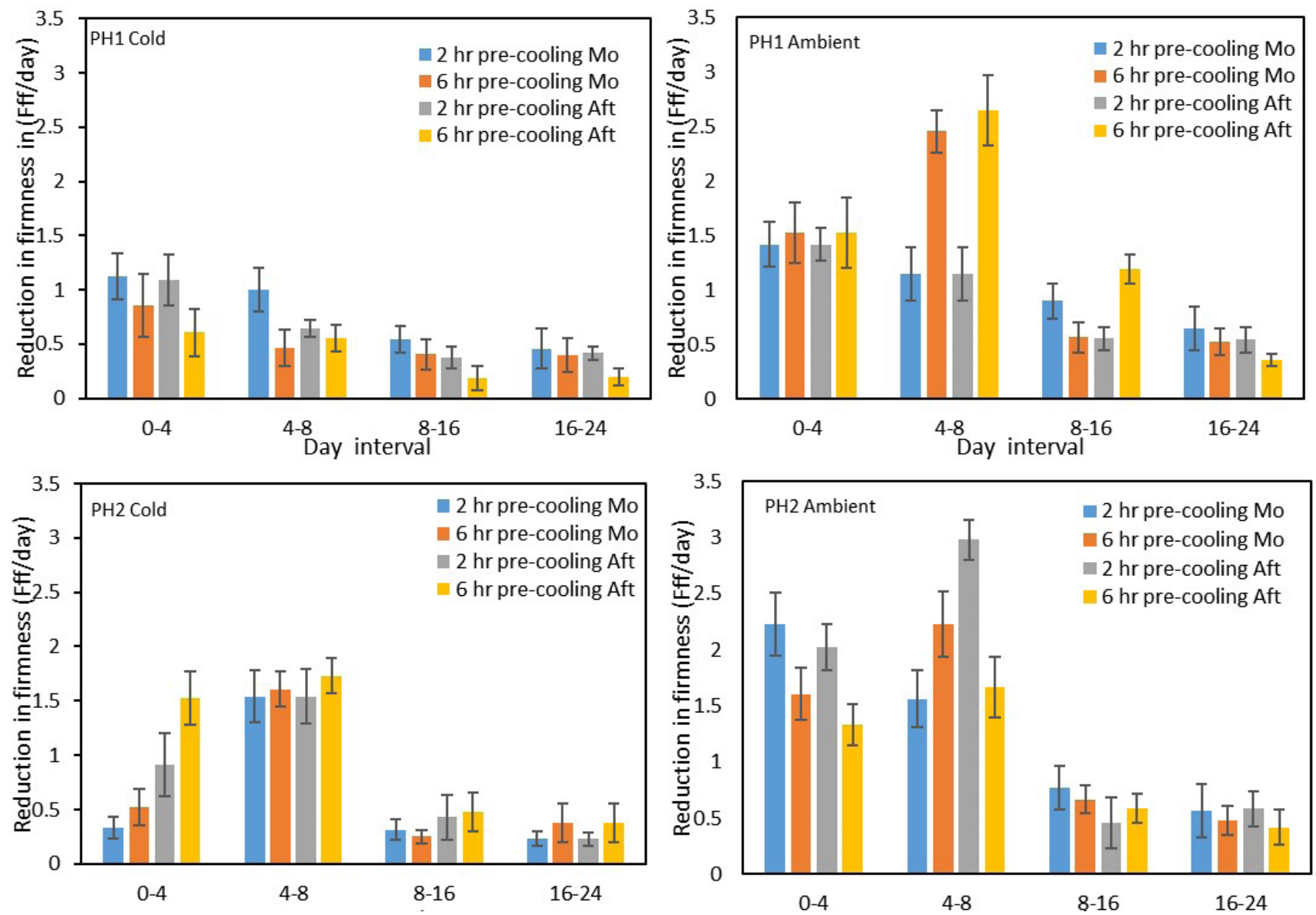

Figure 4. Effect of various treatments on the rate of firmness loss. 
the firmness of samples stored in $\mathrm{PH} 2$, while better road conditions (95\% class A roads) for the transport route to $\mathrm{PH} 1$ explained the non-significance of this factor on the firmness of the samples. The cooler temperatures during harvest at the farm supplying tomatoes to $\mathrm{PH} 1$ (Figure 2a) and subsequent storage in a cold room meant that the cold chain was generally maintained, explaining the minimal effect the time before precooling and harvesting time had on product firmness. The relatively higher ambient temperatures during harvesting of the tomatoes sent to $\mathrm{PH} 2$, the shorter time before pre-cooling and harvesting in the morning, were important factors for the cold stored samples, and this suggests that they may have retarded enzymatic activities by the continuous maintenance of the cold chain during the storage period. A shorter time before pre-cooling and storage under ambient conditions in $\mathrm{PH} 2$ may also have resulted in tomatoes experiencing breaks in the cold chain or temperature abuse as described by Sibomana et al. (2017). The kinetic models developed based on fruit firmness fitted the first order kinetic law well, with $R^{2}$ values ranging from 0.71 to 0.96 (Table 1), and were higher than those reported by Pinheiro et al. (2015).

Further research on the heat flow around the products in lugs or bins using tools such as computational fluid dynamics (CFD) should be carried out in order to establish the temporal and spatial distribution of heat around the products under various stacking patterns, storage and handling conditions.

\subsubsection{Weight loss}

Fruit weight loss significantly $(p \leq 0.05)$ increased between successive sampling days, and was significantly ( $p \leq 0.05$ ) higher for samples transported using bins than those transported using lugs for both pack houses. Similarly, the fruit weight loss of samples stored under ambient conditions was significantly $(p \leq 0.05)$ higher than that of cold stored fruit. Harvesting time significantly $(p \leq 0.05)$ influenced the weight loss of samples stored in $\mathrm{PH} 1$, while the time before precooling was a significant factor affecting the weight loss of fruit stored in $\mathrm{PH} 2$. A reduction in the time before pre-cooling, harvesting at cooler times of the day and storage under ambient or cold conditions in $\mathrm{PH} 1$ had varied effects on the weight loss of the samples handled in bins and lugs. In $\mathrm{PH} 2 \mathrm{a}$ reduction in the time before precooling and harvesting in the morning showed a positive reduction in the weight loss of both ambient and cold stored samples handled using both bins and lugs, with morning harvested samples that were precooled within 2 hours showing the least weight loss for both handling and storage conditions (Figure 5).

Fruit weight loss is primarily driven by evapotranspiration (ARAH et al., 2015) and the rate of respiration (RAB et al., 2013). These processes are both $\mathrm{RH}$ and temperature dependent. Water loss and respiration in stored tomato fruit are primarily driven by the storage temperature, where higher storage temperatures trigger higher weight losses. As observed in this study, ambient stored samples showed higher weight loss than cold stored samples. This observation is consistent with findings reported by Islam and Morimoto (2016). The higher storage temperatures in $\mathrm{PH} 2$ amplified the effects of both the time before pre-cooling and harvesting time on fruit weight loss, the effects of which were not clearly apparent in $\mathrm{PH} 1$ in some cases, due to the lower storage temperatures. Respiration is also driven by mechanical injuries that may trigger undesirable metabolic processes that accelerate ripening and hence weight loss (OPARA; PATHARE, 2014). Products handled using bins exhibited a higher percentage of mechanical injuries (Figure 6). In addition to loss in quality, relatively higher respiration rates may have occurred in tomatoes handled in bins, explaining the higher weight loss observed.

\subsection{4 pH value}

The product $\mathrm{pH}$ value gradually increased during storage with significant $(p \leq 0.05)$ differences being observed between successive sampling days. The storage and handling conditions significantly $(p \leq 0.05)$ influenced the $\mathrm{pH}$ of the products stored in both pack-houses, while the time of harvest was not a significant $(p>0.05)$ contributor to the differences in $\mathrm{pH}$ of the samples from any of the treatments.

Fruit $\mathrm{pH}$ increased with storage for all treatment conditions (Table 2), an observation in agreement with the findings of Anthon et al. (2011). It is also notable that the $\mathrm{pH}$ values of the samples stored in $\mathrm{PH} 2$ were higher than those in $\mathrm{PH} 1$, which suggests that $\mathrm{pH}$ can be used as an indicator of the rate of deterioration, where samples with higher $\mathrm{pH}$ can be deductively inferred to be nearing senescence. The increase in $\mathrm{pH}$ over the storage period can be partially attributed to the progression in fruit ripening, which causes a loss of acid content due to its conversion to sugars through gluconeogenesis (ANTHON et al., 2011).

The $\mathrm{pH}$ of tomato is an important quality parameter that is influenced by the acid content of the fruit (ARAH et al., 2015). Tomato is considered to be a low $\mathrm{pH}$ fruit, and this has a bearing on both its safety against microbial attack and its sensory characteristics (ETEBU et al., 2013). It is generally desirable to maintain the $\mathrm{pH}$ of tomato fruit at optimum levels ( $\mathrm{pH}$ of 4.25) during storage, since higher $\mathrm{pH}$ values result in tomato fruit with altered flavour (ANTHON et al., 2011). The use of cold storage, minimization of multiple handling processes and the prevention of fruit overloading by process re-design (e.g. the use of modular bins instead of the standard bins in bulk handling systems) could reduce fruit damage, as demonstrated in Table 2, which depicts a lower rate of $\mathrm{pH}$ increase in tomato products handled using lugs. 
Effect of infield handling conditions and time to pre-cooling on the shelf-life and quality of tomatoes

Cherono, K. et al.
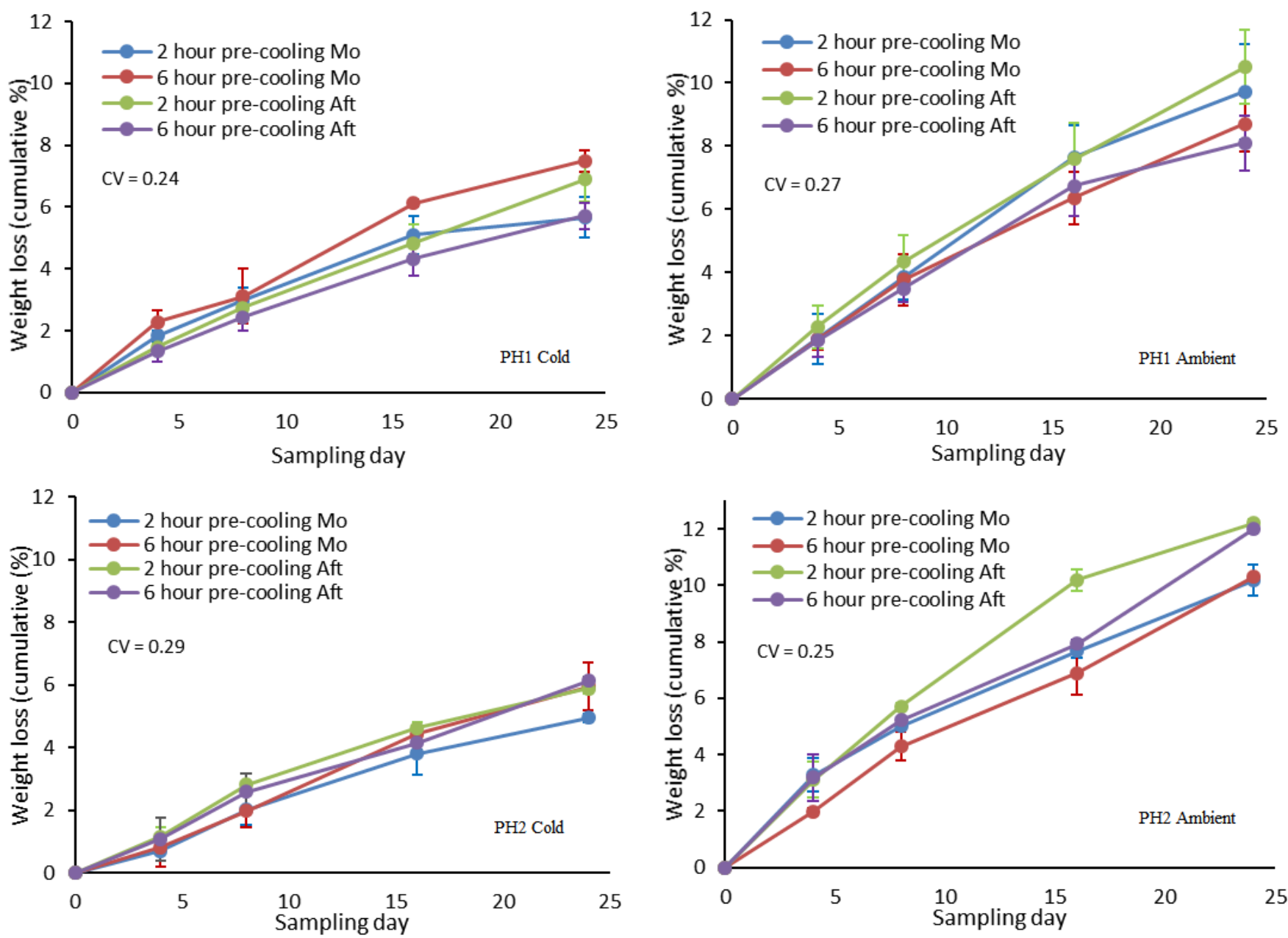

Figure 5. Changes in the cumulative weight loss with storage period for tomato fruit samples subjected to various treatments and stored under ambient and cold storage conditions.
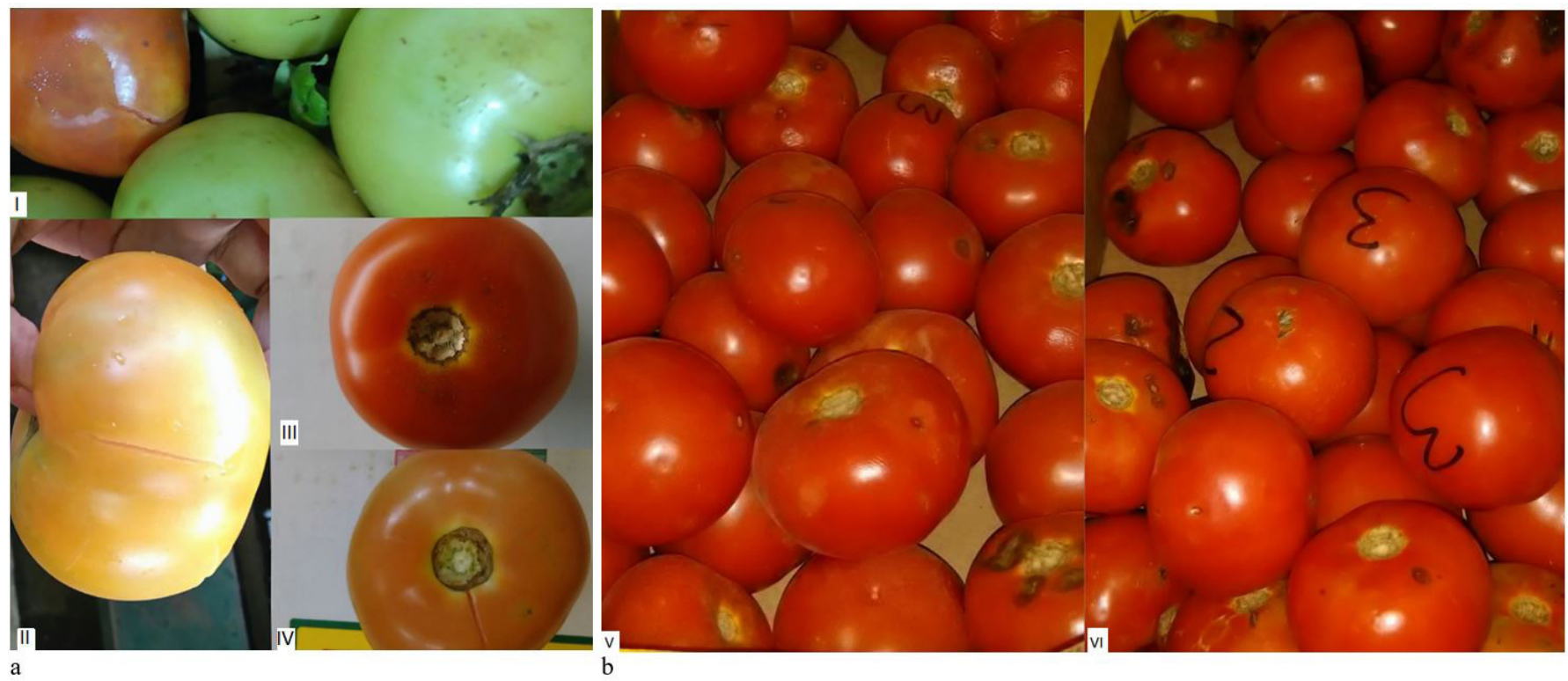

Figure 6. (a) Typical images of tomato fruits, showing damage at the bottom of the bins (I), flattening and cracking of samples transported in bins (III and IV, respectively) and side cuts of samples transported in lugs (II); (b) Typical images of stored tomato showing the long-term effects of bruising that became pronounced in samples handled using bins (V) as compared to lugs (VI). 


\subsection{Subjective quality analysis}

During sampling, approximately $30 \%$ of the samples at the bottom of the bins showed cracks and flattening (Figure $6 a$ ), while $<2 \%$ of the fruit transported using lugs depicted minor side cuts. Fruit transported in lugs also appeared to have less bruising when compared to fruit transported using bins, and this became more apparent with longer storage duration (Figure 6b). Differences in the samples due to the time before pre-cooling and harvesting time could not be visually discerned.

The Sporekill ${ }^{\circledast}$ solution appeared to be effective in managing microbial contamination of the fruits, since mould growth was not observed throughout the entire storage period. However, physiological disorders (cracking, sour rot) were observed towards fruit senescence. These disorders were more prevalent in ambient stored samples after 16 days of storage, with cold stored samples only showing a minimal number of fruits affected by these disorders, as compared to the ambient-stored samples, hence the significant $(p \leq 0.05)$ differences in marketability between cold and ambient stored samples, as depicted in Figure 7. At the end of the storage period, cold stored fruit that was harvested in the afternoon and morning had a marketability of $40 \%$ and $45 \%$, respectively, whereas only $20 \%$ and $25 \%$ of fruit stored under ambient conditions was marketable at the end of the storage period for fruit harvested in the afternoon and morning, respectively.

Visual cues in fresh fruits are the first quality attributes that consumers base their buying decisions upon (SIDDIQUI et al., 2015). Handling conditions and storage temperature appeared to be the major factors that determined the degree of visual damage and the onset of visible physiological disorders. The depth of product-stacking in bins meant that samples in the bottom layer were loaded beyond their bio-yield point, explaining the numerous cracks and flattening depicted by these products as contrasted with samples transported using lugs, which showed minimal bruising. Multiple handling also explained the numerous bruises on fruit transported in bins due to transfer by pouring from the smaller lugs into the larger bins for transport to the pack-houses.

Cold storage is important in maintaining the quality and shelf-life of fresh fruits, since lower temperatures slow down deteriorative metabolic processes such as respiration and transpiration, based on the Q10 concept (SIDDIQUI et al., 2015). Cold and ambient stored samples in $\mathrm{PH} 2$ had significantly $(\mathrm{p} \leq 0.05)$ higher surface temperature compared to those stored in $\mathrm{PH} 1$ (Figure 2b). This may have been due to differences in the cold room temperatures, attributed to maintenance issues in the cold room at $\mathrm{PH} 2$, as well as the geographical differences in the location of $\mathrm{PH} 2$ and $\mathrm{PH} 1$ (about $40 \mathrm{~km}$ apart) that may have caused the differences in ambient temperature conditions (Figure 2b).

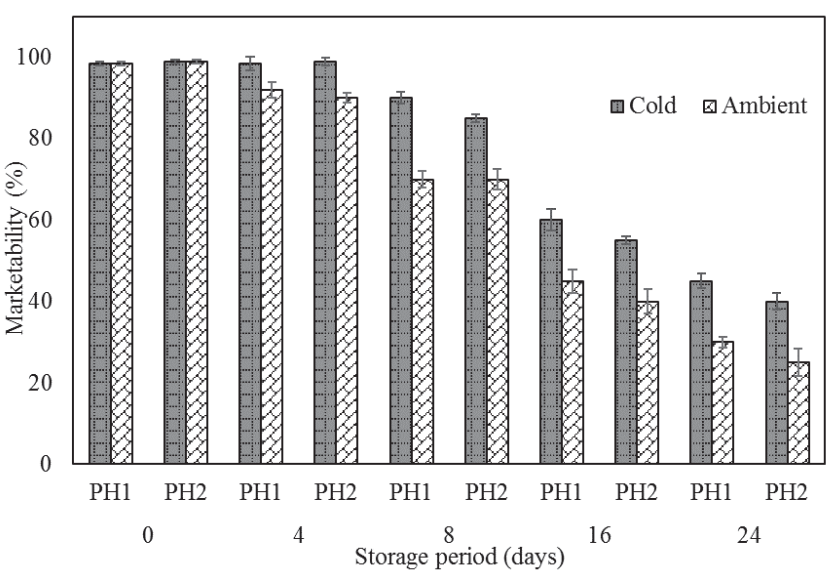

Figure 7. Variation in marketability with storage duration for tomato samples stored in the Rietpol (PH1) and Digale (PH2) pack-houses.

Table 2. Variation in the mean $\mathrm{pH}$ with storage period for tomatoes subjected to various handling and storage treatments. $\mathrm{PH} 1$ and $\mathrm{PH} 2$ designate samples stored in the Rietpol and Digale pack-houses, respectively.

\begin{tabular}{|c|c|c|c|c|c|c|c|c|c|}
\hline \multirow{3}{*}{ Day } & \multirow{3}{*}{$\begin{array}{l}\text { Pack } \\
\text { house }\end{array}$} & \multicolumn{8}{|c|}{ Treatments } \\
\hline & & \multicolumn{2}{|c|}{ Handling } & \multicolumn{2}{|c|}{ Time before precooling } & \multicolumn{2}{|c|}{ Harvest time } & \multicolumn{2}{|c|}{ Storage } \\
\hline & & Bins & Lugs & 2 hours & 6 hours & Morning & Afternoon & Cold & Ambient \\
\hline \multirow{2}{*}{0} & $\mathrm{PH} 1$ & $3.9725 \pm 0.0866^{a}$ & $3.9450 \pm 0.0740^{a}$ & $3.9854 \pm 0.0680^{a}$ & $3.9321 \pm 0.0894^{a}$ & $3.9020 \pm 0.0863^{a}$ & $4.0154 \pm 0.0585^{b}$ & $3.9089 \pm 0.0872^{a}$ & $3.9793 \pm 0.0745^{a}$ \\
\hline & $\mathrm{PH} 2$ & $3.9917 \pm 0.0579^{a}$ & $3.9095 \pm 0.0871^{b}$ & $3.9488 \pm 0.0594^{\mathrm{a}}$ & $3.8267 \pm 0.0927^{a}$ & $3.9666 \pm 0.0788^{a}$ & 3.9346 & $3.9236 \pm 0.0873^{a}$ & $724^{\mathrm{a}}$ \\
\hline \multirow[b]{2}{*}{4} & $\mathrm{PH} 1$ & $4.1983 \pm 0.1084^{a}$ & $4.1438 \pm 0.0679^{a}$ & $4.1821 \pm 0.0719^{a}$ & $3.9900 \pm 0.1078^{b}$ & $4.2125 \pm 0.1061^{a}$ & 4.129 & $4.1415 \pm 0.1188^{a}$ & $692^{\mathrm{a}}$ \\
\hline & $\mathrm{PH} 2$ & $4.1029 \pm 0.0539^{a}$ & $4.0683 \pm 0.0580^{\mathrm{a}}$ & $4.0954 \pm 0.0586^{a}$ & $4.0758 \pm 0.0545^{a}$ & $4.0700 \pm 0.0608^{a}$ & & & \\
\hline \multirow{2}{*}{8} & $\mathrm{PH} 1$ & $4.2767 \pm 0.0950^{a}$ & $4.2825 \pm 0.0904^{\mathrm{a}}$ & $4.3225 \pm 0.1040^{a}$ & $4.2367 \pm 0.0716^{a}$ & $4.3425 \pm 0.1023^{a}$ & 4.2167 & $4.2259 \pm 0.1059^{a}$ & 4.2744 \\
\hline & $\mathrm{PH} 2$ & $4.2342 \pm 0.0915^{\mathrm{a}}$ & $4.2179 \pm 0.0641^{b}$ & $4.2196 \pm 0.0789^{a}$ & $4.2325 \pm 0.0792^{\mathrm{a}}$ & $4.2175 \pm 0.0870^{a}$ & $4.2346 \pm$ & $4.1433 \pm 0.0869^{a}$ & $4.2619 \pm 0.0721^{a}$ \\
\hline \multirow{2}{*}{16} & $\mathrm{PH} 1$ & $4.4571 \pm 0.0742^{\mathrm{a}}$ & $4.3492 \pm 0.0904^{b}$ & $4.4500 \pm 0.0847^{a}$ & $4.4833 \pm 0.0837^{\mathrm{a}}$ & $4.4017 \pm 0.1111^{a}$ & $4.4046 \pm 0.0581^{\mathrm{a}}$ & $4.3548 \pm 0.0803^{a}$ & $4.4230 \pm 0.0967^{a}$ \\
\hline & $\mathrm{PH} 2$ & $4.4271 \pm 1.0019^{a}$ & $4.3746 \pm 0.0679^{b}$ & $4.3588 \pm 0.0765^{a}$ & $4.4429 \pm 0.0898^{a}$ & $4.3742 \pm 0.0856^{a}$ & $4.4275 \pm 0.0855^{a}$ & $4.3526 \pm 0.0697^{a}$ & $4.4211 \pm 0.1019^{a}$ \\
\hline & $\mathrm{PH} 1$ & $4.5604 \pm 0.0988^{a}$ & $4.5275 \pm 0.1041^{a}$ & $4.5633 \pm 0.0916^{a}$ & $4.5246 \pm 0.1101^{a}$ & $4.5675 \pm 0.1045^{a}$ & $4.5204 \pm 0.0974^{a}$ & $4.4230 \pm 0.0790^{\mathrm{a}}$ & $4.6385 \pm 0.0742^{b}$ \\
\hline & $\mathrm{PH} 2$ & $4.6467 \pm 0.0971^{a}$ & $4.5721 \pm 0.0939^{a}$ & $4.6079 \pm 0.0795^{a}$ & $4.6108 \pm 0.1136^{a}$ & $4.5962 \pm 0.0929^{a}$ & $4.6225 \pm 0.1023^{a}$ & $4.4948 \pm 0.0570^{a}$ & $4.6867 \pm 0.0986$ \\
\hline
\end{tabular}

All values are mean \pm SEM. For each pair, different letters in the same row designate a significant difference $(p \leq 0.05)$. 


\section{Conclusion}

Sub-optimal storage temperature conditions, cold chain management and handling during transport are the major contributors to post-harvest losses in tomato supply chains. Under South African commercial fresh tomato production conditions, where there is often more cognizance given to postharvest quality management, multiple handling often increases fruit injuries and exacerbates deterioration in tomato quality by triggering an increase in ethylene production resulting in increased respiration. In this study, at the end of the storage period, $45 \%$ of morning harvested, cold stored tomato and $20 \%$ of afternoon harvested, ambient stored fruit were marketable, respectively. This translates to a difference of $200 \mathrm{~kg} / \mathrm{ton}$ of stored produce. Weight loss mitigation of up to $75 \mathrm{~kg} /$ ton stored can be achieved by harvesting in the morning, precooling within 2 hours and storing in cold storage, when compared to harvesting in the afternoon, precooling after 6 hours and storage in ambient conditions, similar to those in $\mathrm{PH}$ 2. The kinetic models developed showed that storage under ambient conditions in $\mathrm{PH} 2$ resulted in fruit with the shortest shelf life. Reducing the time before pre-cooling and harvesting in cooler times of the day, especially in regions with warm to high ambient temperature, is recommended as one of the industry best practices. It was also noted that in some industrial practices, the delay between harvesting and washing of the fruit may be more than 6 hours, and therefore the results presented in this study would be conservative in terms of quality deterioration, further motivating a reduction in the delay as a recommendation to improve the shelf-life. A process re-design of the handling operations to minimize handling steps, and the use of modular bins that have dual layers, to reduce the depth of tomato fruit during transportation, should be assessed by the industry. Further studies should be carried out to establish the spatial and temporal distribution of heat through and around the stacked units, including optimization of stalking patterns of tomato fruits' bulk handling units during pre-cooling, in order to maximize air circulation and heat loss.

\section{Acknowledgements}

The authors thank the Post-Harvest Innovation Programme (PHI) for funding this research under Grant number 7/2014 and Tomato Producer Organization (TPO) for the PhD scholarship awarded to the first author. We also thank ZZ2 and Steve Mohale's farm for providing the tomato samples and permitting their facilities and resources to be used during this study.

\section{References}

ACEDO JUNIOR, A.; THANH, C. D.; VAN, L. T. S.; LINH, N. T. T.; WEINBERGER, K. Tomato precooling using simple hydrocooler and fruit quality changes during ambient and cold storage. ISHS
Acta Horticulturae, v. 837, n. 837, p. 135-140, 2009. http:// dx.doi.org/10.17660/ActaHortic.2009.837.15.

ANTHON, G. E.; LESTRANGE, M.; BARRETT, D. M. Changes in $\mathrm{pH}$, acids, sugars and other quality parameters during extended vine holding of ripe processing tomatoes. Journal of the Science of Food and Agriculture, v. 91, n. 7, p. 1175-1181, 2011. http:// dx.doi.org/10.1002/jsfa.4312. PMid:21384370.

ARAH, I. K.; AMAGLO, H.; KUMAH, E. K.; OFORI, H. Preharvest and postharvest factors affecting the quality and shelf life of harvested tomatoes: a mini review. International Journal of Agronomy, v. 2015, p. 1-6, 2015. http://dx.doi.org/10.1155/2015/478041.

BECKLES, D. M. Factors affecting the postharvest soluble solids and sugar content of tomato (Solanum lycopersicum L.) fruit. Postharvest Biology and Technology, v. 63, n. 1, p. 129-140, 2012. http://dx. doi.org/10.1016/j.postharvbio.2011.05.016.

CARON, V. C.; TESSMER, M. A.; MELLO, S. C.; JACOMINO, A. P. Quality of mini tomatoes harvested at two maturity stages and kept chilled in three packages. Horticultura Brasileira, v. 31, n. 2, p. 279-286, 2013. http://dx.doi.org/10.1590/S010205362013000200017

ETEBU, E.; NWAUZOMA, A.; BAWO, D. Postharvest spoilage of tomato (Lycopersicon esculentum Mill.) and control strategies in Nigeria. Journal of Biology, Agriculture and Healthcare, v. 3, n. 10, p. 51-61, 2013.

FOOD AND AGRICULTURE ORGANIZATION OF THE UNITED NATIONS - FAO. FAOSTAT. Rome, 2015. Available at: <http:// faostat.fao.org/site/339/default.aspx>. Accessed on: 25 feb. 2016.

HURR, B. M.; HUBER, D. J.; LEE, J. H. Differential responses in color changes and softening of Florida 47' tomato fruit treated at green and advanced ripening stages with the ethylene antagonist 1-Methylcyclopropene. HortTechnology, v. 15, n. 3, p. 617-622, 2005.

ISLAM, M.; MORIMOTO, T. Quality of fresh tomato fruit stored inside a solar adsorption cooling storage system as function of low pressure treatment. Agricultural Engineering International: CIGR Journal, v. 18, n. 3, p. 258-265, 2016.

JEDERMANN, R.; NICOMETO, M.; UYSAL, I.; LANG, W. Reducing food losses by intelligent food logistics. Food Control, v. 77 , p. 221-234, 2017

MACHEKA, L.; SPELT, E.; VAN DER VORST, J. G.; LUNING, P. A. Exploration of logistics and quality control activities in view of context characteristics and postharvest losses in fresh produce chains: a case study for tomatoes. Food Control, v. 77, p. 221-234, 2017. http://dx.doi.org/10.1016/j.foodcont.2017.02.037.

MOURA, S. C. S. R.; PRATI, P.; VISSOTTO, F. Z.; ORMENESE, R. C. S. C.; SANTOS RAFACHO, M. Color degradation kinetics in low-calorie strawberry and guava jellies. Food Science and Technology, v. 31, n. 3, p. 758-764, 2011. http://dx.doi. org/10.1590/S0101-20612011000300032. 
Effect of infield handling conditions and time to pre-cooling on the shelf-life and quality of tomatoes

Cherono, K. et al.

OPARA, U. L.; PATHARE, P. B. Bruise damage measurement and analysis of fresh horticultural produce: a review. Postharvest Biology and Technology, v. 91, p. 9-24, 2014. http://dx.doi. org/10.1016/j. postharvbio.2013.12.009.

PINHEIRO, J.; ALEGRIA, C.; ABREU, M.; GONÇALVES, E. M.; SILVA, C. L. M. Kinetics of changes in the physical quality parameters of fresh tomato fruits (Solanum lycopersicum, cv. 'Zinac') during storage. Journal of Food Engineering, v. 114, n. 3, p. 338-345, 2013. http://dx.doi.org/10.1016/j.jfoodeng.2012.08.024.

PINHEIRO, J.; ALEGRIA, C.; ABREU, M.; SOL, M.; GONÇALVES, E. M.; SILVA, C. L. M. Postharvest quality of refrigerated tomato fruit (Solanum lycopersicum, cv. Zinac) at two maturity stages following heat treatment. Journal of Food Processing and Preservation, v. 39, n. 6, p. 697-709, 2015. http://dx.doi. org/10.1111/jfpp. 12279 .

POLENTA, G.; BUDDE, C.; SIVAKUMAR, D.; NANNI, M.; GUIDI, $S$. Evaluation of biochemical and quality attributes to monitor the application of heat and cold treatments in tomato fruit (Lycopersicon esculentum Mill.). Journal of Food Quality, v. 38, n. 3, p. 153-163, 2015. http://dx.doi.org/10.1111/jfq. 12139.

RAB, A.; REHMAN, H.; HAQ, I.; SAJID, M.; NAWAB, K.; ALI, K. Harvest stages and pre-cooling influence the quality and storage life of tomato fruit. Journal of Animal and Plant Sciences, v. 23, n. 5, p. 1347-1352, 2013.

SIBOMANA, M. S.; WORKNEH, T. S.; AUDAIN, K. A review of postharvest handling and losses in the fresh tomato supply chain: a focus on Sub-Saharan Africa. Food Security, v. 8, n. 2, p. 389-404, 2016. http://dx.doi.org/10.1007/s12571-016-0562-1.

SIBOMANA, M.; ZIENA, L.; SCHMIDT, S.; WORKNEH, T. Influence of transportation conditions and postharvest disinfection treatments on microbiological quality of fresh market tomatoes (cv. Nemo-Netta) in a South African supply chain. Journal of Food Protection, v. 80, n. 2, p. 345-354, 2017. http://dx.doi. org/10.4315/0362-028X.JFP-16-229. PMid:28221979.

SIDDIQUI, M. W.; RODRÍGUEZ, G. V.; SALMERÓN-RUIZ, M.; AGUILAR, G. G.; SIDDIQUI, M. W.; ZAVALA, J. A. Advances in storage of fruits and vegetables for quality maintenance. In: SIDDIQUI, M. W. Postharvest biology and technology of horticultural crops: principles and practices for quality maintenance. Boca Raton: CRC Press, 2015. p. 193-216.

SOUTH AFRICAN DEPARTMENT OF AGRICULTURE FORESTRY AND FISHERIES - SADAFF. A profile of the South African tomato market value chain. South Africa: Directorate of Marketing, 2015. Available at: <www.nda.agric.za/doaDev/sideMenu/Marketing/ Annual\%20Publications/Commodity\%20Profiles/field\%20crops/ Tomato\%20Value\%20Chain\%20Profile\%20\%202012.pdf>. Accessed on: 26 mar. 2016.

TADESSE, T. N.; MOHAMMED I, A.; GEBRESELAS, W. Degradation and formation of fruit color in tomato (Solanum lycopersicum L.) in response to storage temperature. American Journal of Food Technology, v. 10, n. 4, p. 147-157, 2015. http://dx.doi. org/10.3923/ajft.2015.147.157.

TIGIST, M.; WORKNEH, T.; WOLDETSADIK, K. Effects of variety on the quality of tomato stored under ambient conditions. Journal of Food Science and Technology, v. 50, n. 3, p. 477-486, 2013. http://dx.doi.org/10.1007/s13197-011-0378-0. PMid:24425942.

TIJSKENS, L. M. M.; RODIS, P. S.; HERTOG, M. L. A. T. M.; KALANTZI, U.; VAN DIJK, C. Kinetics of polygalacturonase activity and firmness of peaches during storage. Journal of Food Engineering, v. 35, n. 1, p. 111-126, 1998. http://dx.doi. org/10.1016/S0260-8774(98)00003-X.

VERMEULEN, H.; BIENABE, E. Food quality behaviour perceptions and knowledge of South African consumers: a focus on middle and upper socioeconomic groups. Pretoria: National Agricultural Marketing Council, 2010. Task report.

WORKNEH, T. S.; OSTHOFF, G.; STEYN, M. Effects of preharvest treatment, disinfections, packaging and storage environment on quality of tomato. Journal of Food Science and Technology, v. 49, n. 6, p. 685-694, 2012. http://dx.doi.org/10.1007/s13197011-0391-3. PMid:24293687. 